\title{
MODERNITAS DI BETLEHEM VAN JAVA: KONDISI SOSIAL MUNTILAN DAN MENDUT AWAL ABAD KE-20
}

Eka Ningtyas, M.A*

\begin{abstract}
Education is an important element of the opening of the gates of modernity in the Indies. The beginning of the 20th century is the period of development of educational institutions in the Dutch East Indies. Not only educational institutions developed by the government, but also educational institutions developed by religious organizations and private education. This paper focuses on educational institutions developed by missionaries at the beginning of the 20th century in Muntilan and Mendut. This paper aims to see the social dynamics emerging from the presence of mission education institutions in Muntilan and Mendut.
\end{abstract}

Keywords: education, mission, muntilan, mendut.

\begin{abstract}
Abstrak
Pendidikan merupakan satu elemen penting pembuka gerbang modernitas di Hindia Belanda. Awal abad ke-20 merupakan masa berkembangnya lembaga pendidikan di Hindia Belanda. Tidak hanya lembaga pendidikan yang dikembangkan oleh pemerintah, namun juga lembaga pendidikan yang dikembangkan oleh organisasi keagamaan maupun pendidikan partikelir. Tulisan ini memiliki fokus pada lembaga pendidikan yang dikembangkan oleh misionaris pada awal abad ke-20 di Muntilan dan Mendut. Tulisan ini bertujuan melihat dinamika sosial yang muncul dari kehadiran lembaga pendidikan misi di Muntilan dan Mendut.
\end{abstract}

Kata kunci: pendidikan, misi, muntilan, mendut

\section{A. Pendahuluan}

Awal abad ke-20 merupakan sebuah periode yang menarik untuk dikaji. Pidato Wilhelmina yang melegalkan pendidikan di Hindia Belanda pada tahun 1901, sekaligus menjawab kritik dari kaum sosialis yang peduli pada keadaan masyarakat di koloni Belanda, memberikan angin segar pada menjamurnya lembaga pendidikan di Hindia Belanda. Salah satu lembaga pendidikan yang muncul adalah pendidikan berbasis agama yang dikembangkan oleh organisasi maupun lembaga keagamaan seperti Muhammadiyah pada tahun 1912 maupun kegiatan yang diinisiasi oleh misionaris pada akhir abad ke-19.

Menarik melihat bagaimana tangan dingin dari para misionaris Katolik mampu mengubah wajah Mendut, sebuah desa kecil di dekat candi Borobudur menjadi tujuan belajar gadis-gadis kecil di Jawa Tengah dan sekitarnya. Selain itu, para bruder dan pastor mampu memberikan perubahan pada Muntilan, sebuah desa yang terletak di Utara kali Putih Magelang menjadi pusat kegiatan pendidikan misi yang maju, hingga hari ini. Tulisan ini membawa kita pada nostalgia keadaan pendidikan misi di Jawa Tengah pada awal abad ke-20 yang menjadi cikal-bakal pendidikan misi di Indonesia kemudian hari.

\section{B. Pendidikan Misi di Muntilan dan Mendut}

\section{Pertumbuhan Penduduk dan Struktur Sosial Masyarakat Muntilan dan Mendut}

\footnotetext{
* Staf Pengajar Ilmu Sejarah FIS UNY. ekaningtyas@uny.ac.id
} 
Muntilan merupakan daerah beriklim sejuk yang terletak tidak jauh dari Yogyakarta. Dari Yogyakarta naik otto atau kereta api 20 kilometer sampai garis batas kesultanan, kemudian menyebrangi sungai Krasak dan masuk ke wilayah Karesidenan Kedu. Jalan raya terasa menanjak namun tidak curam, letaknya pada permulaan lereng gunung Merapi yang terlihat di sebelah kanan atau Timur, dan di sebelah kiri jalan atau Barat merupakan sungai Progo. Masyarakat Muntilan sejatinya hingga hari ini masih mengatakan bahwa Gunung Merapi letaknya di Utara atau disebelah Timur menurut geografisnya.

Sejarah mencatat pada awal abad 20 di Muntilan, arus perubahan mengalir begitu deras ${ }^{1}$. Diberlakukannya politik etis yang disahkan oleh Ratu Wilhelmina pada tahun 1901, dan pada periode ini pendidikan menurut van Deventer serta para kaum liberal merupakan kunci dari perubahan yang diinginkan ${ }^{2}$. Pendidikan menjadi sebuah jembatan modernitas bagi masyarakat pribumi pada umumnya di Hindia Belanda, namun hanya segelintir golongan saja yang mendapat hak untuk merajut mimpi dari bangku pendidikan. Hal ini berkaitan dengan pembagian kelas sosial dalam masyarakat Jawa. ${ }^{3}$ Hanya masyarakat yang tergolong dalam kelas elit pribumi saja yang mendapat hak untuk mengenyam bangku pendidikan.

Sarekat Jesus menawarkan kesempatan bagi masyarakat pribumi yang bukan dari golongan priyayi untuk menempuh pendidikan di sekolah-sekolah Misi ${ }^{4}$. Pendidikan menjadi sarana efektif yang dilakukan untuk mendekatkan masyarakat dengan Gereja. Selain itu juga untuk mencerdaskan masyarakat yang masih buta huruf, sehingga mampu berkomunikasi aktif dan memperbaiki kualitas hidupnya. Pendidikan mempengaruhi perubahan hidup setiap anggota masyarakat. Menurut van Deventer tidak ada perubahan yang berarti tanpa tenaga-tenaga kerja pribumi yang berpendidikan, yang kelak akan mengemban tugas tersebut. Pendidikan menjadi sorotan ketika Kaum cendikiawan di Muntilan dan Mendut secara fenomenal mampu menggeser kedudukan dari golongan priyayi yang terdiri dari bangsawan dan pangreh. Hal ini terjadi akibat ketidaksiapan golongan priyayi itu untuk menghadapi gerak zaman yang bergejolak kuat.

\footnotetext{
${ }^{1}$ Kuntowijoyo, "Muslim Kelas Menengah Indonesia 1910-1950: Sebuah Pencarian Identitas", Paradigma Islam, (Bandung, Mizan, 1991), hlm 80-81.

${ }^{2}$ Ide kesejahteraan bagi pribumi dicetuskan oleh van Deventer dalam majalag De Gids pada tahun 1899 dengan judul een eereschuld atau "Hutang Kehormatan", oleh karenanya menurut van Deventer hutang kehormatan tersebut harus dibayar dengan cara peningkatan Irigasi, Imigrasi penduduk dan Pendidikan bagi masyarakat pribumi.

Lihat: Suhartono, Sejarah Pergerakan Nasional dari Budi Utomo sampai Proklamasi: 1908-1945 (Yogyakarta: Pustaka Pelajar, 2001, hlm. 15-17. Lihat juga pada M.C. Ricklefs, (terj.). Sejarah Indonesia Modern, (Yogyakarta: Gadjah Mada University Press, 1995) hlm. 227.

${ }^{3}$ Sebelum abad XX, dalam strata sosial masyarakat di Jawa Priyayi menduduki tingkat paling atas. Priyayi itu sendiri berasal dari kaya yayi yang maksudnya adalah adik atau kerabat dari Raja. Dalam buku Sartono Kartodirjo, et al., perkembangan Peradaban Priyayi, Beliau menjelaskan mengenai definisi dari priyayi menurut para ahli sejarah antara lain Van Niel, Palmier, Sutherland, scherer, Geertz dan Soemarsaid Moertono. Menurut Van Niel priyayi adalah pejabat-pejabat administratif pemerintahan tertentu dan dengan jabatannya tersebut mereka berhak menyandang gelar raden, raden mas atau den mas. Menurut Leslie H. Palmier priyayi adalah anak keturunan Bupati yang hidup feudal di luar komunitas desa, sehingga asal keturunan yang menentukan status kebangsawanan. Menurut Sutherland priyayi adalah golongan yang menguasai dan memonopoli jabatan-jabatan pada administrasi pemerintahan dalam negeri sehingga tidak mempermasalahkan asal usul keturunan. Menurut Scherer priyayi adalah pegawai pemerintahan kolonial Belanda sedangkan menurut Clifford Geertz, priyayi adalah elit pegawai negeri yang berakar dari kerajaan Hindi-Jawa jauh sebelum masa kolonial yang memiliki nilai hidup sendiri. Sedangkan menurut Soemarsaid Moertono priyayi adalah lapisan sosial diantara raja beserta para keturunan raja.

${ }^{4}$ Sekolah merupakan salah satu langkah yang dilakukan serikat Jesuit dalam melaksanakan pewartaan, pada rintisan awal pendirian sekolah putri mendut, para suster Fransiskanes mendirikan sekolah nonformal yang mengajarkan berbagai kerajinan dan pendidikan bagi perempuan. Setelah sukses dengan sekolah nonformal baru pada tahun 1908 sekolah formal diresmikan.
} 
Sejalan dengan perkembangan perekonomian dan perluasan bidang pemerintahan beserta administrasi pemerintahan, disisi lain maka muncul permintaan akan tenaga kerja dalam jumlah besar. Dengan itu kaum cindekiawan Muntilan dan Mendut mampu mengisi bangku-bangku pemerintahan dan secara perlahan muncul sebagai golongan elit modern ${ }^{5}$.

\section{Muntilan}

Pada peta tahun 1922 yang dikeluarkan oleh Hermeten door Den Topografischen Dienst in 19021904, Muntilan merupakan sebuah Onderdistrict yang berada pada District dengan nama yang sama, Muntilan pada Afdeling Magelang, Karesidenan Kedu. District Muntilan terdiri dari lima Onderdistrict yaitu: Muntilan, Doekoen, Mendoet, Sawangan dan Moengkid ${ }^{6}$. Muntilan merupakan daerah strategis dimana dilewati jalur utama kereta api penghubung antara Yogyakarta - Magelang - Ambarawa. Sebelum kedatangan Misionaris Katolik di wilayah Muntilan sudah lebih dulu masuk Zending Protestan yang berpusat di daerah Karangjoso. ${ }^{7}$

Disebutkan bahwa pada masa pemerintahan Kolonial Belanda wilayah Residentien Kedoe termasuk dalam Proviencie Midden Java dan meliputi wilayah yang luas, terbagi menjadi enam Regentschappen, yaitu: Regentschap Magelang yang terdiri dari tujuh district yaitu District Magelang, District Bandongan, District Tegalrejo, District Grabag, District Muntilan, District Salam dan District Salaman. Regentschapp Wonosobo terdiri dari lima Districten yaitu: District Wonosobo, District Garoeng, District Leksono, District Sapoeran, dan District Ngadisono. Regentschappen Temanggung terdiri dari lima Districten yaitu: District Temanggung, District Kaloran, District Pringsoerat, District Parakan, dan District Tjandiroto. Regentschap Poerworejo terdiri dari tiga Districten yaitu District Poerworejo, District Loano, dan District Tjangkrep. Regentshap Koetoardjo terdiri dari empat Districten yaitu; District Koetoardjo, District Kemiri, District Pitoeroh, dan District Poerwodadi. Regentschap Keboemen terdiri dari empat Districten yaitu; District Keboemen, District Alihan, District Koetowinangoen, dan District Premboen.

Dibawah wilayah Districten masih terdapat pembagian wilayah yang disebut Onderdistricten yang kekeuasaannya dibawahi oleh Assistant-Wedana, Pribumi yang ditunjuk oleh pemerintah kolonial untuk mengatasi dan melaporkan apabila terdapat permasalahan di wilayah Onderdistrict. Dulu wilayah Kedoe dan Bagelen merupakan wilayah Vorstenlanden dari kerajaan Nyayogyakarta Hadiningrat namun setelah perang Jawa kemudian Kedoe pada tahun 1811, dan Bagelen pada tahun 1830 resmi masuk menjadi wilayah Gouvernement ${ }^{8}$.

\footnotetext{
${ }^{5}$ Robert van Niel (terj.), Munculnya Elit Modern Indonesia (Jakarta: Pustaka Jaya, 1984), Hlm. 54.

${ }^{6}$ Hal yang sama juga disebutkan dalam Geillustreerde Encyclopaedie van Nederlandsch-indie door G.F.E. Gonggryp (oud-gouverneur van Sumatra's Westkust), (N.V. Leidsche Uitgeversmaatschappij, Leiden 1934), HIm. 56.

${ }^{7}$ Karangjoso merupakan sebuah desa kecil atau pedukuhan sama seperti pada masa pemerintahan Hindia Belanda Karangjoso masuk dalam wilayah karisidenan Bagelan. Sebelum masuk dalam wilayah residensi Belanda pada tahun 1830, secara administratif Bagelan merupakan wilayah Monconegoro dari Kasultanan Mataram (vorstenlanden) dan secara tradisional wilayah ini merupakan wilayah kejawen. Pada tahun 1901 wilayah Bagelan menjadi bagian dari karesidenan Kedu. Ada sesuatu yang unik pada umat Kristen Karangjoso, pemimpin mereka kyai Sadrach mampu melakukan inkulturasi agama Kristen dengan budaya jawa dan ajarannya dikenal dengan "Kristen Mardiko" dan oleh pemerintahan Hindia Belanda Kristen Mardiko terlalu banyak dipengaruhi oleh unsur Islam, Kejawen dan Takhayul.

Lihat : Himayatul Ittihadiyah, "Petani dan Kristenisasi ; Konversi Agama Masyarakat Petani Perkebunan di Karangjoso, Bagelan 1870-1990” tesis Program Studi Sejarah Pasca Sarjana Universitas Gadjah Mada, 2002. Hlm. $1-11$.

${ }^{8}$ Opcit. G.F.E. Gonggryp. Hlm. 643.
} 
Muntilan dalam peta tahun 1922, diapit oleh empat deretan Pegunungan; di wilayah Utara Pegunungan Lemah, di Timur Gunung Merapi dan Pegunungan Merbabu, di Selatan Pegunungan Gendol dan pegunungan Ukir serta Pegunungan Sipodang di bagian Barat. Dikelilingi oleh deretan pegunungan membuat Muntilan dikelilingi banyak sungai, antara lain; Sungai Blongkeng, Sungai Pabelan, Sungai Poetih dan juga Sungai Droedjo yang bermuara pada Sungai Progo. Dengan banyaknya jumlah sungai di Muntilan, menjadilan Muntilan sebagai kawasan pertanian dan perkebunan yang subur.

Disebutkan dalam Geillustreerde Encyclopaedie van Nederlandsch-Indie karya G.F.E Gonggryp bahwa :

"De rivier Progo stroomt in het Zuiden uit. Belangrijke plaatsen zijn

Temanggoeng, Wonosobo, Keboemen, Koetoardjo, Poerworedjo, alle met spoor

of tram bereikbaar. De residentien is zeer vruchtbaar. Door de dichtheid der

bevolking zijn er echter niet zoo veel particuliere ondernemingen. Devoornaamste

landbouwproducten zijn suikerriet, tabak, thee en kina",9.

Muntilan masuk dalam wilayah gouvernement yang menjadi kawasan perkebunan tembakau serta pertanian padi yang subur. Pengadaan perkebunan yang ditanami dengan tanaman ekspor mengubah aktivitas ekonomi tradisional menjadi ekonomi modern. Sebagai penunjang kehidupan perusahaan perkebunan, dibutuhkan sarana dan prasarana terutama masalah produksi dan distribusi barang. Pengadaan prasarana jalan, jembatan serta sarana alat angkutan baik untuk mobilitas produksi maupun penumpang menjadi penting di Muntilan. Sehingga pada tahun 1898 didirikan jalur kereta api penghubung yang melewati Muntilan. ${ }^{10}$

Berdasarkan sensus tahun 1905, penduduk District Muntilan terdiri dari 30 orang Eropa, 1400 masyarakat Tionghoa, 13 masyarakat Arab dan 110.000 masyarakat pribumi. ${ }^{11}$ Jumlah penduduk Onderdistrict Muntilan pada sensus yang dilaksanakan oleh pemerintahan Hindia Belanda tahun 1920 yaitu 25.064 jiwa yang terdiri dari Pribumi, Eropa dan masyarakat Timur asing seperti Arab dan Tionghoa.

Tabel 1.2 Jumlah Penduduk pada Onderdistrict Muntilan tahun 1905

\begin{tabular}{|c|c|c|c|c|c|c|c|c|c|c|c|c|}
\hline \multirow{3}{*}{$\begin{array}{l}\text { Onder } \\
\text { Distrik }\end{array}$} & \multirow{2}{*}{\multicolumn{3}{|c|}{ Eropa }} & \multirow{2}{*}{\multicolumn{3}{|c|}{ Pribumi }} & \multicolumn{6}{|c|}{ Timur Asing } \\
\hline & & & & & & & \multicolumn{3}{|c|}{ Tionghoa } & \multicolumn{3}{|c|}{ Arab } \\
\hline & $\mathrm{L}$ & $\mathrm{P}$ & $\mathrm{Jml}$ & $\mathrm{L}$ & $\mathrm{P}$ & Jml & $\mathrm{L}$ & $\mathrm{P}$ & $\mathrm{Jml}$ & $\mathrm{L}$ & $\mathrm{P}$ & Jml \\
\hline Muntilan & \begin{tabular}{|l|}
3 \\
8
\end{tabular} & \begin{tabular}{|l|}
1 \\
6
\end{tabular} & 54 & $\begin{array}{c}11.4 \\
02\end{array}$ & $\begin{array}{c}12.3 \\
42\end{array}$ & $\begin{array}{c}23.74 \\
4\end{array}$ & 704 & 558 & 1262 & 4 & - & 4 \\
\hline \multirow[t]{2}{*}{ Jumlah } & \multicolumn{3}{|c|}{ Laki-laki } & \multicolumn{3}{|c|}{ Perempuan } & \multicolumn{6}{|c|}{ Total } \\
\hline & \multicolumn{3}{|c|}{12.148} & \multicolumn{3}{|c|}{12.916} & \multicolumn{6}{|c|}{25.064} \\
\hline
\end{tabular}

Sumber: Uitkomsten der in de maand November 1920 gehouden volkstelling, dalam Sensus Penduduk tahun 1920, hlm. 80.

Pada Tabel 1.2 menunjukkan secara akurat jumlah penduduk pada Onderdistrict Muntilan tahun 1920 dan dapat dilihat kenaikan jumlah masyarakat Eropa sejak tahun 1905

\footnotetext{
9 Opcit, G.F.E. Gonggryp, hlm. 643.

${ }^{10}$ Naskah Sumber Arsip: Dari Merapi Hingga Orde Reformasi, BP2KDE Kabupaten Magelang, 2008. HIm. 24.

${ }^{11}$ Encyclopedie van Nederlandsch Oost-Indie II (Leiden: N.V v/H E.J. Brill, 1918), hlm. 765
} 
dengan jumlah 30 orang untuk seluruh wilayah Distrik Muntilan, sedangkan pada tahun 1920 meningkat menjadi 54 orang untuk wilayah Onderdistrict Muntilan saja.

Kurun waktu 15 tahun peningkatan jumlah penduduk Eropa di Onderdistrict Muntilan ini berkaitan dengan mulai berkembang pula Muntilan sebagai kawasan Misi Katolik di wilayah Jawa bagian Tengah. Kenaikan jumlah penduduk ini disebabkan oleh semakin baiknya sarana transprtasi ke Muntilan, karena sarana transportasi berpengaruh besar terhadap mobilitas penduduk. ${ }^{12}$ Kenaikan jumlah dan kepadatan penduduk di Muntilan merupakan salah satu gejala demografi yang terjadi selama masa kolonial.

Mayoritas masyarakat Muntilan adalah pemeluk agama Islam, namun sampai pertengahan abad ke-20 masih banyak masyarakat yang tidak sungguh-sungguh menunaikan ibadah atau rukun Islam. Koentjaraningrat berpendapat dalam karyanya, Javanese Culture bahwa agama dari golongan masyarakat ini adalah merupakan klasifikasi dari agama Islam di Jawa yang disebut sebagai agami Jawi, sedangkan bagian lain disebut dengan agami Islam santri. ${ }^{13}$ Menurut teori yang dikembangkan oleh Clifford Geertz menyebutkan klasifikasi yang berbeda yaitu golongan pertama disebut abangan sedangkan golongan kedua disebut santri. ${ }^{14}$

Muntilan merupakan daerah mancanegara Mataram yang dulu pernah masuk dalam daerah vorstenlanden, maka jumlah masyarakat abangan cukup banyak. Ini menjadi benang merah mengenai berkembang pesatnya agama Katolik apabila dibandingkan dengan daerah lain di pulau Jawa, terutama di daerah pesisir yang cukup kuat pengaruh tradisi santri-nya. Ketika masyarakat abangan belum memahami dan menjalankan Ajaran Islam dengan sungguh-sungguh, biasanya cenderung memiliki ketertarikan lebih untuk mendidik putra-putri mereka di sekolahsekolah misi. Sekolah misi lebih menjanjikan peluang bagi masyarakat pribumi dari pada sekolah milik pemerintah. Sementara itu di sekolah misi pelajaran mengenai agama Katolik diberikan secara intensif dan melembaga, maka proses konversi di Muntilan mulai menemui titik terang.

\section{Mendut}

Mendut merupakan salah satu onderdistrict di wilayah District Muntilan, berbatasan langsung dengan Sungai Elo, Sungai Oedal dan Sungai Progowati yang ketiganya bermuara pada Sungai Progo dan terletak di kaki Bukit Menoreh. Di Mendut terletak peninggalan berupa candi dari kerajaan Mataram Kuno, yang berada dekat dengan sungai Elo, dimana nantinya tepat disamping candi berdiri kweekschool dan frobelschool khusus putri.

Seperti dalam cuplikan lagu anak-anak yang sering dinyanyikan siswi sekolah putri Mendut:

"Tussen al die hoge Bergen Staat het

Klooster van Mendoet wendt ge u

Naar 't Noord of Zuiden Niets dan

Bergen die u groet

Dalam lagu tersebut tersirat bahwa Mendut terletak di daerah yang dikelilingi gununggunung. Pada baris ketiga pada bait tersebut menyebutkan bahwa apabila menengok ke Utara atau Selatan, tidak ada yang lain selain gunung-gunung tinggi. Terletak di daerah yang

\footnotetext{
12 W.F. Wertheim, The Indonesian Town Studies in Urban Sociology (A. Manteau S.A. Bruxelies: W. van Hoeve Ltd. 1958) hlm. 17.

${ }^{13}$ Koentjaraningrat, Javanese Culture, (Singapore: Oxford University Press, 1985), hlm. 317.

${ }^{14}$ Clifford Geertz, Abangan, Santri, Priyayi: Dalam Masyarakat Jawa, (Jakarta: Pustaka jaya, 1983)
} 
dikelilingi gunung-gunung tentunya membuat daerah Mendut menjadi sejuk dan dingin, menurut celotehan masyarakat sekitar, dulu Mendut sejuk dan dingin sama seperti daerah di Utara Muntilan seperti daerah Wonolelo, Keteb, Windusajan tidak seperti Mendut saat ini yang mulai panas dan sumuk. Tidak mengherankan apabila dulu di Mendut menjadi salah satu daerah pemasok tanaman ekspor tembakau.

Terletak di dekat tiga bangunan peninggalan Buddha pada masa syailendra yang kaya akan budaya dan kesenian Buddha, sehingga tidak mengherankan apabila masyarakatnya kaya akan kebudayaan baik seni ukir, seni lukir, seni tari bahkan seni pahat pada batu. Dalam peta tahun 1922, dapat dilihat bahwa mendut merupakan daerah yang sudah memiliki jalan yang mampu dilewati ottobus. ${ }^{15}$ Jalur jalan yang dimaksud dalam peta tahun 1922 sama dengan jalur jalan yang masih dipergunakan hingga sekarang. Dari arah Muntilan lurus hingga sampai di Pabelan, kemudian belok ke kiri dan lurus hingga melewati Candi Mendut. Jalur ini terus melintas menyebrangi Sungai Progowati hingga masuk pertigaan Sawitan yang bila belok kiri akan sampai di daerah Borobudur, sedangkan bila lurus maka sampai di daerah Blondo yang mana menjadi titik pertemuan dengan jalan raya Muntilan - Magelang - Pringsurat.

Tabel 1.3 Pembagian Administratif di Hindia Belanda 1889-1842

\begin{tabular}{|l|l|l|}
\hline \multicolumn{2}{|c|}{ Wilayah di Bawah Pengawasan Langsung } & \multicolumn{1}{c|}{$\begin{array}{c}\text { Wilayah di Bawah Pengawasan Tidak } \\
\text { Langsung }\end{array}$} \\
\hline \multicolumn{1}{|c|}{ Jawa } & \multicolumn{1}{|c|}{ Luar Jawa } & \multicolumn{1}{c|}{ Jawa - Luar Jawa } \\
\hline Provinsi (sejak 1925) & Gouvermenent (sejak & Residensi \\
Residensi & 1936 ) & Native Island \\
Afdeling / Regensi & Residensi & \\
District & Afdeling Used Division \\
Subdistrict & Onderafdeling & \\
Desa & District & \\
& Subdistrict & \\
& Village /Clan & \\
\hline
\end{tabular}

Sumber: Hans Gooszen, A Demographic History of The Indonesian Archipelago, 1880-1942, (Leiden; KITLV Press, 1999), Hlm, 22

Tersedianya jalur transportasi yang layak menunjukkan bahwa Mendut merupakan daerah yang cukup maju karena pembangunan jalan raya pada masa kolonial tidak dibangun hanya untuk mobilitas penduduk melainkan demi kelancaran mobilitas produksi komoditas eksport, seperti tembakau dan tebu yang banyak ditemukan di wilayah karesidenan Kedu. Wilayah Karesidenan Kedu merupakan daerah strategis yang memiliki kesuburan tanah untuk ditanami berbagai komoditas eksport, serta letak geografisnya tidak jauh dengan pelabuhan Semarang.

\footnotetext{
${ }^{15}$ Pada masa liburan sekolah, para siswa dari sekolah putri Mendut memperoleh waktu untuk berlibur selama satu minggu dengan dihantar bis dari muka gerbang sekolah hingga di shelter tertentu yang kemudian dijemput oleh keluarga masing-masing. Setelah waktu liburan usai, para siswa akan dijemput kembali di shelter yang telah ditentukan dengan bis milik sekolah. Mengenai Bis yang melewati jalan hingga ke sekolah Putri Mendut banyak disebutkan dalam novel Balada Dara Dara Mendut dan buku Jalan Emansipasi Perempuan Katolik Pionir dari Mendut 1908-1943. lihat: Mangun Wijaya S.J., Balada Dara Dara Mendut, (Yogyakart: Kanisius, 1994) dan Iswanti, Jalan Emansipasi Perempouan Katolik Pionir dari Mendut 1908-1943 (Yogyakarta: Kanisius 2008)
} 
Selain subur, masyarakat Mendut juga memiliki keragaman penduduk. Menurut data sensus tahun 1920, jumlah penduduk Mendut berjumlah 19.283 jiwa, terdiri dari 14 jiwa masyarakat Eropa, 19.268 jiwa pribumi dan 11 jiwa masyarakat Tionghoa. Hal ini menjadi menarik, karena masyarakat Tionghoa di Mendut memiliki keterbukaan akan adanya pewartaan Katolik di wilayah tersebut. Hal ini dapat dilihat pada batu nisan masyarakat Tionghoa yang terdapat di kerkhof Mendut yang masih menjadi satu kawasan dengan sekolah Katolik putri.

Masyarakat Tionghoa peranakan memiliki tradisi memakamkan anggota keluarganya yang meninggal dunia di daerah yang tinggi atau perbukitan. Hal ini berkaitan dengan kepercayaan bahwa semakin tinggi seseorang dimakamkan maka semakin dekat dengan tuhan Thian (langit). Namun hal menarik disini, justru masyarakat Tionghoa Mendut memakamkan keluarganya di kerkhoof milik Gereja Katolik dengan batu nisan berbentuk salib dari semen dan diletakkan sejajar dengan makam lain. Tentunya ini menunjukkan adanya singgungan budaya Tionghoa dengan kepercayaan baru mereka yaitu Agama Katolik.

Karel Steenbrink dalam karyanya yang berjudul Chatolics in Indonesia a Dokumented History 1808-1942 menyebutkan bahwa sebelum dirintis oleh Hoevenaars, wilayah Mendut yang kelak akan menjadi kawasan sekolah Katolik putri dulunya merupakan pabrik minyak kacang milik seorang Tionghoa yang kemudian dibeli oleh Sarekat Jesus untuk didirikan sebuah gereja $^{16}$. Ungkapan ini menarik karena dengan adanya sebuah pabrik minyak kacang di Mendut pada periode sebelum tahun 1898, menandakan bahwa para Jesuit bukan satu-satunya pembawa modernitas di wilayah tersebut.

\section{Situasi pendidikan di Muntilan dan Mendut}

Pemerintah Hindia Belanda cukup diskriminatif terhadap pribumi, dan sengaja mengelompokkan menjadi golongan masyarakat yang statusnya hanya mampu menjadi kelas bawahan di perusahaan swasta, maupun di institusi pemerintahan. Pribumi sengaja dibentuk secara sistematis sebagai kelompok dalam rantai makanan terbawah, bukan sebagai kelas elit priyayi. Kecuali bagi para anak pejabat De Inlandse Hoofden seperti Asisten Wedana, Wedana dan Bupati, mereka tetap dipertahankan sebagai golongan yang memiliki hak istimewa untuk mewarisi atau menduduki jabatan-jabatan sebagai kepala daerah maupun hak istimewa lain seperti dalam pekerjaan maupun dalam pendidikan. Sehingga hal tersebut mendukung berkembangnya sistem pemerintahan feodal di Hindia Belanda bahkan sampai akhir masa kolonial walaupun semangat liberalism telah dielu-elu-kan pada awal abad ke-20.

"Di mana lagi gadis Jawa akan bersekolah, jika tidak disana. Sekolah-sekolah Gupermen (Gouvernement ) hanya untuk anak-anak priyayi paling rendah anak Bendoro Raden Asisten Wedono atau kepala stasiun yang pakai topi merah dengan pita emas itu" ${ }^{\text {. }}$.

Pada masa kolonialisme Belanda, Hindia Belanda, masyarakat pribumi hanya dianggap orang yang bodoh, kotor dan pemalas. Hal semacam modernisme dianggap sebagai representasi dari orang-orang Eropa yang memiliki sikap rajin, pandai, bersih, disiplin tinggi dan pintar berbahasa Belanda, oleh sebab itu apabila ada pribumi yang bisa dan pintar berbahasa Belanda secara otomatis derajatnya lebih tinggi dari pada pribumi yang lain, karena bahasa Belanda menjadi syarat bagi penerimaan calon pegawai negeri pada saat itu.

Sanitasi maupun fasilitas kesehatan dan pendidikan belum mencukupi dikalangan masyarakat pribumi, sehingga pribumi masih memerlukan pembangunan sarana dan prasarana

\footnotetext{
${ }^{16}$ Karel Steenbrink, Chatolics in Indonesia a Dokumented History 1808-1942, Volume 2: The Spectacular Growth of a Self-Confident Minority 1903-1942, (Leiden: KITLV Press, 2007). Hlm. 370-381

${ }^{17}$ Y.B. Mangunwijaya, Pr. Balada Dara-dara Mendut, (kanisius; Yogyakarta, 1993). Hlm. 5.
} 
dalam meningkatkan mutu kehidupan. Namun untuk mencapai kesetaraan dalam bidang pendidikan pun, pribumi Hindia Belanda menunggu terlalu lama hingga tahun 1901, padahal faktanya pendudukan oleh pedagang Belanda maupun Pemerintah negeri Belanda sudah berlangsung sejak abad ke-16.

Hal mendasar lain yang menjadi perhatian utama para Jesuit ketika tiba di Muntilan adalah mengenai bagaimana membangun kedekatan emosional antara orang pribumi dengan agama Katolik. Beberapa langkah dilakukan untuk membangun ikatan tersebut, pertama pemahaman mengenai bahasa Jawa bagi para pastor sangat diperlukan sebagai factor penunjang pada keberhasilan pelaksanaan misi pewartaan misi ${ }^{18}$. Bahasa menjadi sarana utama bagi para pastor dalam memberikan pemahaman mengenai ilmu-ilmu kekristenan, terutama bagi masyarakat pribumi Jawa yang sangat jumlahnya dalam pemahaman berbahasa Belanda. Kedua, proses Penerjemahan kitab suci, doa-doa dan liturgi perlu dilakukan untuk mempermudah pemahaman baik itu dari orang Jawa terhadap kepercayaan yang baru diperkenalkan oleh misionaris Jesus, serta memungkinkan mereka dalam melaksanakan ritual dengan pendekatan budaya.

Kondisi seperti ini tentu berbeda dengan dalam penyebaran ajaran Islam. Dalam Islam, pemeluknya akan menggunakan bahasa suci, bahasa arab dalam berhubungan dengan Allah. Penulisan kitab suci menggunakan bahasa Arab dan pembacaannya juga menggunakan bahasa Arab. Dalam berdoa pun umat Islam menggunakan bahasa Arab walaupun dapat pula berdoa menggunakan bahasa sesuai dengan bahasa yang digunakan, misal menggunakan bahasa Jawa maupun bahasa Melayu. Namun untuk bacaan ritual agama seperti sholat dan ngaji akan selalu menggunakan bahasa Arab.

Seperti yang disebutkan oleh Stuart O. Robson dalam penerjemahan Doa Bapa Kami ke dalam bahasa Jawa:

"Kanjeng Rama Kawula

Kanjeng Rama kawula ing suwarga,

Asma Dalem kaluhurna

Kraton dalem mugi rawuha

Karsa Dalem kalampahana

Wonten ing donya kados ing swarga

Kawula nyuwun rejeki kangge sapunika

Sakathahing lepat nyuwun pangapunten Dalem

Kados dene anggen kawula ugi ngapunten dhateng sesama

Kawula nyuwun tinebihna saking panggodha

Saha linuwarna saking piawon. Amin ${ }^{19}$.

18 Pada waktu itu para pastor belum menguasi bahasa Jawa, mungkin sekali para pengajarnya terdiri dari mereka yang bukan katolik. Pengajaran itu hanya merupakan pemikat sebagai percobaan untuk dapat berhubungan dengan penduduk setempat.

Lihat: P. Paulus Bus O.C.D., Missie Onderwijs in Ned Indi, 1808-1941, Disertatio ad lauream in fakultate Missionologica apud Pont. Athenaeum Urbanianum de Propaganda Fide Moderanto, 1949. Naskah. Koleksi Perpustakaan Kolese Ignatius Yogyakarta, 78 M 49: 143. dalam Abdurrahcman Surjomiharjo, Kota Yogyakarta Tempo Doeloe sejarah sosial 1880-1930, (komunitas Bambu: Yogyakarta, 2008). Hlm. 112.

${ }^{19}$ Stuart O. Robson, Speaking to God in Javanese, dalam majalah L'Homme. 34e Annee, No. 132, Anthropologie de la priere: Rites oraux en Asie du Sudest (Oktobre-Decembre 1994), Hal. 133-142. Mengenai penerjemahan Doa Bapa Kami dan Salam Maria kedalam bahasa setempat juga dilakukan oleh Fransiskus Xaverius, ketika bertugas di Maluku pada tahun 1546 yang disertai keterangan tambahan untuk memperdalam iman.

Lihat juga, A. Heuken S.J., "Ensiklopedi Popular Tentang Gereja Katolik di Indonesia", (Yayasan Cipta Loka Caraka, Jakarta; 1989), Hlm. 83. 
Robson juga menambahkan tulisan terjemahan Salam Maria ke dalam bahasa Jawa :

"Sembah Bekti

Sembah bekti kawula, dewi maria kekasihing Allah

Pangeran nunggil ing panjenengan dalem

Sami-sami wanita Sang Dewi pinuji piyambak

Saha pinuji ugi wohing salira dalem, Sri Yesus

Dewi Maria, ibuning Allah,

kawula tiyang dosa sami nyuwun pangestu dalem

Samangke tuwin benjing dumugining pejah. Amin

Tentunya pada penerjemahan ini menjadi sangat penting menggunakan pendekatan kebudayaan. Lihat penggunaan kata Kawula untuk menggantikan kata kami yang secara etimologi berarti budak atau hamba sahaya, bukan menggunakan kata kula sebagai pengganti kami atau saya yang dalam unggah-ungguh boso jowo termasuk kata ngoko yang njangkar atau tidak sopan, (we dalam bahasa Inggris), masyarakat Jawa menggunakkan bahasa tertinggi Kanjeng sebagai arti kata dari Jesus dalam bahasa Jawa. Jesuit berhasil mengakulturasikan antara doa dalam bahasa Belanda diterjemahkan menjadi doa dalam bahasa Jawa yang masuk akal dan mudah untuk dimengerti oleh masyarakat Jawa.

Bagaimana cara yang mudah dimengerti bagi masyarakat Jawa untuk memahami konsep Lamb of God yang apabila di bahasa Jawakan menjadi Cempening Allah, sehingga proses penerjemahan menjadi sebuah proses yang sangat penting disini. A. Visser menyebutkan dalam artikelnya:

"Sebetulnya Bahasa Jawa adalah himpunan beberapa bahasa serumpun yang harus ditakar penggunaannya dengan teliti untuk dapat mencerminkan hubungan antar pribadi dengan tepat. Terhalang oleh pengetahuan tersebut,bahasa Jawa saya menjadi sangat lambat. Untuk dapat lebih mahir berbahasa Jawa, saya tinggal dengan seorang guru bahasa Jawa selama beberapa bulan, itu pun ternyata tidak ada hasilnya, saya tetap bodoh dalam bahasa Jawa. Dua tahun kemudian, ketika saya boleh memilih antara berdinas di Jawa atau di luar Jawa dalam sisa masa kerja saya, saya memilih yang kedua. ${ }^{20 "}$

Dapat dilihat betapa sulit mempelajari bahasa dan kebudayaan Jawa bagi para pekerja Eropa di Hindia Belanda saat itu, namun para Jesuit di Muntilan dengan sangat baik mampu menerjemahkan Doa Bapa Kami dan Salam Maria ke dalam bahasa Jawa, tanpa mengurangi makna dari Doa tersebut dalam bahasa aslinya. Penerjemahan Doa-Doa kedalam bahasa Jawa, memberikan dampak baik bagi masyarakat Jawa yang ingin merasakan dan memaknai berdoa menggunakan agama wong londo, namun dapat merasakan makna doa tersebut dalam bahasa Jawa.

\section{Kesimpulan}

Modernitas di Muntilan dan Mendut pada awal abad ke-20 dibuka melalui kran pendidikan misi yang diinisiasi oleh Sarekat Jesus. Penduduk Muntilan dan Mendut memiliki

\footnotetext{
${ }^{20}$ A. Visser, "Dari Yogyakarta ke Nias" penyunting S.L Vand der Wal, Kenang-kenangan Pangrehpraja Belanda 1920-1942, (Djambatan; Jakarta, 2001). Hlm. 219.
} 
kesempatan menikmati pendidikan dan mampu melakukan stratifikasi sosial ke atas. Ada kecenderungan pendidikan yang ditawarkan oleh misionaris memiliki agenda kristenisasi masyarakat Muntilan dan Mendut. Dapat kita lihat bagaimana proses integrasi yang dilakukan Gereja Katolik pada penduduk Muntilan dan Mendut melalui penerjemahan doa salam maria maupun doa bapa kami ke dalam bahasa jawa.

\section{Daftar Pustaka}

Abdurrahcman Surjomiharjo, Kota Yogyakarta Tempo Doeloe sejarah sosial 1880-1930, (komunitas Bambu: Yogyakarta, 2008). Hlm. 112.

A. Heuken S.J., "Ensiklopedi Popular Tentang Gereja Katolik di Indonesia”, Yayasan Cipta Loka Caraka, Jakarta; 1989

A. Visser, "Dari Yogyakarta ke Nias" penyunting S.L Vand der Wal, Kenang-kenangan Pangrehpraja Belanda 1920-1942, Djambatan; Jakarta, 2001.

Clifford Geertz, Abangan, Santri, Priyayi: Dalam Masyarakat Jawa, (Jakarta: Pustaka jaya, 1983.

Encyclopedie van Nederlandsch Oost-Indie II (Leiden: N.V v/H E.J. Brill, 1918

Geillustreerde Encyclopaedie van Nederlandsch-indie door G.F.E. Gonggryp (oud-gouverneur van Sumatra's Westkust), N.V. Leidsche Uitgeversmaatschappij, Leiden 1934

Hans Gooszen, A Demographic History of The Indonesian Archipelago, 1880-1942, Leiden; KITLV Press, 1999.

Iswanti, Jalan Emansipasi Perempouan Katolik Pionir dari Mendut 1908-1943 Yogyakarta: Kanisius 2008.

Karel Steenbrink, Chatolics in Indonesia a Dokumented History 1808-1942, Volume 2: The Spectacular Growth of a Self-Confident Minority 1903-1942, Leiden: KITLV Press, 2007

Koentjaraningrat, Javanese Culture, Singapore: Oxford University Press, 1985.

Kuntowijoyo, "Muslim Kelas Menengah Indonesia 1910-1950: Sebuah Pencarian Identitas", Paradigma Islam, Bandung, Mizan, 1991.

M.C. Ricklefs, Sejarah Indonesia Modern, Yogyakarta: Gadjah Mada University Press, 1995

Robert van Niel, Munculnya Elit Modern Indonesia, Jakarta: Pustaka Jaya, 1984.

Stuart O. Robson, "Speaking to God in Javanese", dalam majalah L'Homme. 34e Annee, No. 132, Anthropologie de la priere: Rites oraux en Asie du Sudest, Oktobre-Decembre 1994.

Suhartono, Sejarah Pergerakan Nasional dari Budi Utomo sampai Proklamasi: 1908-1945, Yogyakarta: Pustaka Pelajar, 2001.

W.F. Wertheim, The Indonesian Town Studies in Urban Sociology (A. Manteau S.A. Bruxelies: W. van Hoeve Ltd. 1958) hlm. 17.

Y.B. Mangunwijaya, Pr. Balada Dara-dara Mendut, kanisius; Yogyakarta, 1993. 
